\title{
Montagem e Otimização de Ozonizador: Aplicação em Emulsões de Óleo em Água
}

\author{
Miralda L. e Silva*, Renato F. Dantas, Carolina S. F. Picone.
}

\begin{abstract}
Resumo
O ozônio vem sendo utilizado por reagir com vários tipos de compostos orgânicos e por possuir um elevado potencial de oxidação que é maior que o do peróxido de hidrogênio e o do cloro. A quitosana é um do derivado desacetilado da quitina, onde o grau de desacetilação é uma das características mais importantes, pois influenciará diretamente na solubilidade da mesma. Uma das alternativas para diminuir os impactos ambientais causados por coagulantes convencionais no tratamento de efluentes industriais e domésticos é o uso de coagulante natural como a quitosana. Assim, para que haja a remoção do óleo emulsionado é necessário promover inicialmente a quebra da emulsão, através da adição de agentes emulsificantes ou polímeros floculantes, visando à desestabilização do sistema e a separação das fases. O objetivo desse trabalho foi testar o ozônio para desestabilizar emulsões óleo em água com a presença da quitosana. Os resultados demonstraram que o ozônio foi eficiente na separação da fase oleosa e alterou algumas características da quitosana.
\end{abstract}

\section{Palavras-chave}

Ozônio, Quitosana, Emulsão.

\section{Introdução}

O ozônio possui alto potencial de oxidação $\left(E^{0}=2,07 \mathrm{~V}\right)$, reagindo com diversos compostos orgânicos. Em água se torna instável, ele se decompões rapidamente, reduzindo sua concentração inicial e obtendo como subproduto a formação de radical hidroxila $(\mathrm{OH})^{1}$. Por ser instável, não pode ser armazenado e deve ser produzido no local de sua utilização, através de uma célula onde o ar ou oxigênio puro recebe uma descarga elétrica produzida por uma fonte elétrica de alta voltagem, formando assim o ozônio ${ }^{3}$.

O óleo presente na água impede as trocas gasosas e penetração da luz, causando morte das espécies de animais e vegetais. Pode ser encontrado na água nas formas livre, disperso, quimicamente emulsionado, "dissolvido e solubilizado" e aderido a superfícies de partículas ${ }^{2}$.

Este projeto tem o objetivo extrair quitosana de resíduos de camarão, que será posteriormente aplicado em emulsões e passará pelo processo de ozonização, com o intuito de testar o ozônio na separação do óleo disperso na água.

\section{Resultados e Discussão}

Etapa I: para a obtenção da quitosana, as cascas de camarão passaram pelo processo de pré-lavagem, desproteinização, desmineralização e desacetilação. A caracterização da quitosana foi realizada pelo grau de desacetilação a partir da titulação potenciométrica linear, obtendo o valor de 49,5\%. Quando testada como agente desestabilizante, a quitosana ajudou no processo de separação da fase oleosa.

Etapa II: $300 \mathrm{~mL}$ das emulsões contendo $70 \%$ de solução aquosa, $30 \%$ de óleo e $1 \%$ de quitosana foram expostas ao ozônio em duplicata. A Figura 1 e a Tabela 1 apresentam, respectivamente, o sistema para a produção de ozônio e as características gerais de cada emulsão.

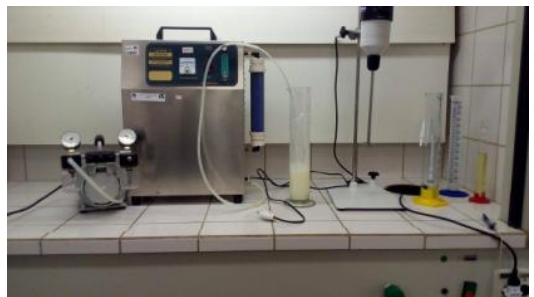

Figura 1: Sistema de produção de ozônio.

Tabela 1: Tipos de emulsões testadas e seus componentes.

\begin{tabular}{c|ccc}
\hline Emulsão & $\begin{array}{c}\text { Tipo de } \\
\text { quitosana }\end{array}$ & Solvente & Ozônio \\
\hline E1s & Obtida/Diluída & Ag.Mili-Q & Não \\
E1o & Obtida/Diluída & Ág.Mili-Q & Sim \\
E2s & Obtida/Diluída & Tampão & Não \\
E2o & Obtida/Diluída & Tampão & Sim \\
E3s & Obtida/Pó & Tampão & Não \\
E3o & Obtida/Pó & Tampão & Sim \\
E4s & Obtida/Pó & Tampão & Não \\
E4o & Obtida/Pó & Tampão & Sim \\
E5s & Comercial/Diluída & Tampão & Não \\
E5o & Comercial/Diluída & Tampão & Sim \\
\hline
\end{tabular}

\section{Conclusões}

A partir dos resultados obtidos conclui-se que a quitosana extraída em combinação com o ozônio foram eficientes na desestabilização das emulsões aumentando a velocidade de separação da fase oleosa. Com isso podemos propor que o ozônio hidrolisou as quitosanas, induzindo-as a oxidação lipídica. Sendo assim, é possível dizer que a aplicação desta combinação pode tornar mais fácil e eficiente o tratamento de efluentes.

\section{Agradecimentos}

Os autores agradecem ao CNPq e ao PIBIC pelo financiamento desta pesquisa.

\footnotetext{
${ }^{1}$ Almeida, E.; Assalin, M. R.; Rosa, M. A.; Duran N. Química Nova, 2004, v. 27, n. 5, p. $818-824$

${ }^{2}$ Fidelis. O. \& Robert C. A. EPA, 1998, v. 600, n. 2, p. 69-78.

${ }^{3}$ Ornelas A. Pontifícia Universidade Católica, 2004, 38 p.
} 